\title{
Using of Thermal Analysis in the Industrial Practice - Consumption Reduction of Grain- Refinement Master Alloy and Optimization of Computer Simulation Results
}

\author{
Marko Grzincic $^{1)}$, Mile Djurdjevic ${ }^{2)}$, Florian Dirnberger ${ }^{3)}$ \\ 1) Process Engineering, Nemak Slovakia Ltd., Ladomerská Vieska 394, 96501 Žiar nad Hronom, Slovakia, \\ marko.grzincic@nemak.com \\ ${ }^{2)}$ Product Development Center, Nemak Linz Ltd., Zeppelinstrasse 24, 4030 Linz, Austria, mile.djurdjevic@nemak.com \\ ${ }^{3)}$ Process Engineering, Nemak Linz Ltd., Zeppelinstrasse 24, 4030 Linz, Austria, florian.dirnberger@nemak.com
}

The solidification process of a metal or alloy is accompanied by the evolution of heat the magnitude of which depends on the various phases that form during the solidification. Recorded temperature-time data can yield quantitative information about the alloy solidification process. Such a plot is called a cooling curve and the general name given to the technique is thermal analysis. The cooling curve serves as a "finger print" of the solidification process and can be used to predict the structure of the test sample and consequently the actual casting. The aim of this paper is to show the ability of the thermal analysis technique in order to predict some of the key solidification parameters, which can be used to monitor and improve the quality of the casting. In addition, some of the results collected from the cooling curve can be used as an input data in existing software packages in order to improve their accuracy.

Keywords: thermal analysis, cooling curve analysis, grain-refinement, master alloy AlTi5B1, dendrite coherency point

\section{References}

[1] TIllovÁ, E., CHALUPOVÁ, M., HURTAlOVÁ, L., ĎURINIKOVÁ, E: Quality control of microstructure in recycled Al-Si cast alloys. Manufacturing Technology, 11, No. 12 - 2011, p. 70 - 76.

[2] BÄCKERUD, L., CHAI, G., TAMMINEN, J.: Solidification Characteristics of Aluminum alloys. Volume 2. AFS-SKANALUMINIUM, 1986, p. 95-105.

[3] Cibula, A.: The Mechanism of Grain Refinement of Sand Castings in Aluminum Alloys. J. Ins. Metals vol. 76, p. 312.

[4] APELIAN, D., SIGWORTH, G. K., WAHLER, K. R.: Assessment of Grain Refinement and Modification of AlSi Foundry Alloys by Thermal Analysis. AFS Transaction, 1984, 161, p. 297-307.

[5] MURTY, B. S., KORI, S. A. AND CHAKRABORTY M.: Grain Refinement of Aluminum and its Alloys by Heterogeneous Nucleation and Alloying. International Materials Reviews, Vol. 47, No. 1, p. 3-29, 2002.

[6] KASHYAP, K. T. AND CHANDRASHEKAR, T.: Effects and Mechanisms of Grain Refinement in Aluminum Alloys. Bull. Mater. Sci. Vol. 24, No. 4, August 2001, p. 345-353.

[7] JOHNSSON, M.: Grain Refinement of Aluminum Studied by Use of a Thermal Analytical Technique. Thermochimica Acta 256, 1995, p. 107-121.

[8] EASTON, M. A. AND STJOHNS, D. H.: A Model of Grain Refinement Incorporating Alloy Constitution and Potency of Heterogeneous Nucleant Particles. Acta Materialia, 49, 2001, p. 1867-1878.

[9] PASCIAK, K. J. AND SIGWORTH, G. K.: Role of Alloy Composition in Grain Refining Aluminum 319 Alloy. AFS Transactions, p. 329-338.

[10] SIGWORTH, G. K. AND GUZOWSKI, M. M.: Grain Refining of Hypo-Eutectic Al-Si Alloys. AFS Transactions, Vol. 93, 1985, p. 907-912.

[11] DIRNBERGER, F.: Einfluss der Begleitelemente auf die Wirkung von Kornfeinung und Veredelung in der Legierung G-AlSi8Cu3. Diploma work, Fachhochschule Oberösterreich, Wels, Austria, November 2009.

[12] CAMPBELL, J.: Feeding Mechanisms in Castings. AFS Cast Metal Research Journal, 1969, p. 1-8.

[13] CHAI, G.: Dendrite Coherency During Equiaxed Solidification in Aluminum Alloys. Chemical Communications. No. 1, Stockholm University, Stockholm, Sweden 1994. 